\title{
Islamic Pastoral Care and the Development of Muslim Chaplaincy
}

\author{
Ibrahim J. Long, MA, GC \\ Interfaith Chaplain's Association \\ University of Alberta
}

Bilal Ansari, MA, GC

Williams College

\section{Abstract}

An increasing number of public institutions are providing Muslim chaplaincy services. However, Muslim chaplaincy is still an emerging profession and, as such, the exact function of a Muslim chaplain as well as his or her distinction from other care providers is often unclear among other professionals. To shed light on this developing field, this article presents a descriptive definition of Muslim chaplaincy together with essential elements of its Islamic foundations, professional development, and practice. It is based on a review of relevant literature, consultation with Muslim chaplains, and the views and experiences of the authors.

Keywords: Muslim chaplaincy, pastoral care, spiritual care, American Muslims, Islam, religion, counseling, mental health

While many Muslim organizations are overwhelmed with the social, spiritual, and psychological needs of their faith community, an increasing number of religious leaders, counselors, and Muslim student organizations are recognizing the benefit of Muslim chaplaincy services. By working within healthcare, educational, military, and correctional institutions, Muslim chaplains can directly support the needs of those who may be experiencing -- or at risk of experiencing -- spiritual, social, psychological, and physical distress. However, the concept of Muslim chaplaincy is still new to many Muslims who also profess confusion over the use of terms such as "chaplain" and "pastoral care" within an Islamic context. Moreover, they may also wonder: Is Muslim chaplaincy au- 
thentically Islamic? How is it different from being an imam? And, in what ways is Muslim chaplaincy supportive and reflective of the care offered by psychologists, psychiatrists, and other counselors? Through a survey of material and in consultation with experts in the field, this article sheds light upon the emerging profession of Muslim chaplaincy, including its foundations within the Islamic tradition, professional development, and unique approach to the pastoral care of Muslims through a case study.

\section{Roots of Islamic Pastoral Care}

Expressions of spiritual concern for others is neither new nor distinctly Islamic. Generations of Muslims have felt a religious imperative to care for those who are experiencing spiritual, social, psychological, and physical distress, using methods based upon the caregivers' understanding of the Qur'an and the teachings and practices of the Prophet Muhammad. Since his time, visiting those in distress and offering pastoral care has been seen within the Islamic tradition as a pious and sacred duty owed to both Muslim and non-Muslim family members, friends, and neighbors. This duty has been illustrated by the Prophet Muhammad through the metaphor of a shepherd ( $\left.r{ }^{\prime} i\right)$. In one such account he is recorded as having said, "All of you are shepherds and each of you are responsible for his flock;" thereafter explaining that community leaders, husbands, and wives each are shepherds in their own ways to those they care for. Moreover, words that derive from similar linguistic roots have been used in connection with various themes in Islamic spirituality and particularly in relation to one's duty to be mindful of trusts (amanat) and the care of others. Historically, Muslim scholars have understood this hadith as a moral imperative upon all people to carefully shepherd those they are bound to. It is also noted in the Qur'an that for some time (until it was forbidden; see 2:104 and 4:46), the Companions (the term used to refer to Prophet Muhammad's friends and allies) used to request the Prophet's attention by saying "be mindful of us" (raa'inaa), which is derived from the same triliteral root as the word for shepherd $(r-'-y)$. Similarly, another word from the same root is used elsewhere in the Qur'an, though this time to refer to those who are attentive (raa'oona) or "shepherds" (trans. Pickthall; 23:8) to their duties and trusts $(23: 8,70: 32)$.

The description of the Prophet Muhammad as being like a shepherd has also been used by al-Abbas, the Prophet's uncle and Companion, in a report after the Prophet Muhammad's death:

[I swear by God that the] Messenger of Allah did not die until he had left the way as a clear open road [ . . . ] No shepherd of sheep and goats who took them over the mountain tops beating down the leafy branches of tall 
thorny trees for them and plastering their watering trough with clay with his own hands was more exhausted and wearied by hard work than was the Messenger of Allah among you (Cited in Ansari, 2011, p. 29).

This metaphorical description summarizes the Prophet Muhammad's life as like that of a shepherd who was utterly devoted to the protection and care for his flock. These Quranic and historical evidences are important when examining the origins and the use of the phrase "Islamic pastoral care," because the word pastor derives from the Latin word for shepherd.

\section{Is Pastoral Care Islamic?}

Through an examination of what we know of his life and "the core beliefs and practices of Muslims, it becomes evident that pastoral care and concern for those who are suffering, sick or poor forms an intrinsic part of the Islamic tradition" (Gilliat-Ray, Ali, \& Pattison, 2013, p. 25). This is further evidenced by the holistic approach of Muslim scholars and physicians who have historically "involved the spiritual" alongside the "psychological, physical, and moral aspects of being" in their understanding and treatment of various illnesses (Isgandarova, 2005, p. 93). However, a number of contributors to dialogue within the field of chaplaincy, including Doehring (2006), have expressed that the term "pastoral care" can only be used in reference to the "Christian and Jewish religious traditions" (p. 8) and cannot include Islam or the spiritual care provided by Muslim chaplains. We do not accept this claim. Rather, we argue that pastoral care is, indeed, Islamic. Moreover, it is a spiritually rich way to describe the care offered by Muslim chaplains who journey beside individuals as they traverse the valleys and "the mountain tops" of their own life's journey.

\section{Professional Development}

As Gilliat-Ray, Ali, and Pattison (2013) note, "Muslim chaplains have been vital to the gradual institutionalization of Islam in many public institutions" (p. 23). In the United States, Muslim chaplaincy initially formed as a response to the religious needs of incarcerated Muslims. Some sources cite that as early as the 1940s (and at least by the 1960s), local imams and Muslim community leaders visited prisons to provide prayer services and support the religious needs of Muslim inmates. Notably, representatives from the Nation of Islam-referred to by Jackson (2005) as a "proto-Islamic black-nationalist spin-off movement" (pg. 3) - provided a significant portion of these services with a focus on the care of African American inmates (Kassam-Remtullah, 2010). Although there is still need for further research in the early development of Muslim chaplaincy, 
it is known that the Nation of Islam contributed greatly to the rights afforded to incarcerated Muslims. Over the course of their work in correctional institutions, representatives from the Nation of Islam witnessed the varying barriers inmates faced when seeking to follow their religious traditions. In the 1960s, they advocated for the religious rights of inmates in US courts and won the right for the incarcerated to receive religious accommodation (Kowalski \& Becker, 2015). These efforts helped ensure the protection of Muslim religious practices in American prisons and paved the way for the further development of Muslim chaplaincy in state and federal correctional facilities (Kowalski \& Becker, 2015).

Following these lawsuits, state and federal correctional systems "sought help from Muslim communities to accommodate inmate religious needs" (Kowalski \& Becker, 2015, p. 21). In response, an increasing number of imams and community leaders were employed or volunteered as religious service providers in correctional institutions (Kowalski \& Becker, 2015). However, the services they provided often lacked consistency, and focused primarily on simply meeting the most basic of religious needs (Kowalski \& Becker, 2015). This remained the case throughout the 1970s, though a significant shift occurred in 1984 with the hiring of the first full-time Muslim chaplain by the Federal Bureau of Prisons (Kowalski \& Becker, 2015). "Since then," Kassam-Remtullah (2010) notes, "the prison system has employed more Muslim chaplains than any other American institution" (p. 100).

\section{Expanding into Other Sectors}

Beyond state and federal prisons, Muslim chaplaincy continued to expand into the US military, universities, and healthcare institutions (among others). Muslim staff and community members became increasingly involved as volunteer religious care providers, while some institutions began to actively seek out Muslims with specialized education in pastoral care; this was true particularly in hospitals, educational institutions, the armed forces, and, to a lesser extent, police forces and corporations (Kassam-Remtullah, 2010). By 1993, the first Muslim chaplain was appointed to the US Army and, in 1999, the first fulltime Muslim chaplain was hired at Georgetown University (Kowalski \& Becker, 2015) with Brown, Princeton, Yale, Duke, and others soon following suit (Kassam-Remtullah, 2010). However, despite these important developments, Muslims have still been "underserved at most American institutions" (KassamRemtullah, 2010, p. 100). Kassam-Remtullah (2010) links this to a combination of factors, including "ignorance about chaplaincy among the Muslim community, inadequate numbers of people pursuing careers in Muslim chaplaincy, and insufficient resources to hire Muslim chaplains" (p. 100). However, these conditions "began to change in the first decade of the $21^{\text {st }}$ century" (Kassam- 
Remtullah, 2010, p. 100) with the development of accredited Islamic chaplaincy programs and increased outreach by professional chaplaincy associations looking to accommodate and train Muslims in clinical pastoral education.

The first accredited Islamic chaplaincy program was established in 2000 at the Hartford Seminary under the leadership of Ingrid Mattson. The program was initially created to meet the needs of a growing number of Muslims looking for an Islamic equivalent to the Christian Master of Divinity (M.Div) degree; a requirement to serve as a chaplain in a professional capacity. From its inception, Hartford Seminary's Islamic chaplaincy program adopted core features also found in Christian and Jewish chaplaincy programs (such as courses in faith-based counseling and ethics), but Hartford Seminary supplemented these with relevant courses in Islamic law (fiqh), Islamic Spirituality, and mental health from an Islamic perspective (among other courses). Since the successful launch of the program many alumni have not only gone on to serve in the US Military and the Canadian Armed Forces, but also at universities, hospitals, and state and federal correctional institutions across North America. Furthermore, based on the success of the Hartford Seminary's program and a growing interest in Muslim chaplaincy, other North American graduate schools have followed suit with Islamic chaplaincy/pastoral programs of their own including the American Islamic College, Bayan Claremont, and Emmanuel College of Victoria University at the University of Toronto.

\section{Developing Professional Associations}

While Muslim chaplaincy is not limited to healthcare, educational, military, and correctional institutions, its history and continual work within these sectors has significantly contributed to the profession and its ongoing development. The professional demands of each sector push Muslim chaplains to continually further their education, counseling skills, and professional competencies. However, as Muslim chaplains look for opportunities for professional development, they often find that a majority of the professional literature and training opportunities still reflect a predominantly Christian framework (Kowalski \& Becker, 2015). Moreover, despite the growing number of Muslim chaplains, they are still relatively few in comparison to their Christian and Jewish counterparts. All of this has contributed to a feeling of isolation as Muslim chaplains look to better understand and articulate their professional identities in light of the particulars of their faith, their institutional setting, and the needs of the diverse people they serve.

This reality has made it necessary for Muslim chaplains within the field to develop their own professional Muslim chaplaincy associations, such as the Association of Muslim Chaplains (AMC), the Association of Campus Muslim Chaplains (ACMC), and others. By joining together in professional associa- 
tions, Muslim chaplains open themselves up to the collective wisdom and experience of their fellow colleagues while contributing to the further development of the profession. Furthermore, professional conferences, retreats, and seminars such as those organized by AMC and ACMC, allow for members to engage in discussions on relevant issues, to debate the best ways to integrate contemporary research, and to share their knowledge of counseling skills and traditional Islamic practices and resources.

\section{Integrating Religion, Psychology, and the Social Sciences}

In comparison to other forms of counseling and faith-based care, Muslim chaplaincy is unique in that it weaves principles and practices from the traditional Islamic sciences (e.g., fiqh, kalam, tasawwuf) together with a psychological understanding of wellbeing, healing and growth. This holistic approach is indicative of the practices of premodern Muslim physicians. However, as Gilliat-Ray, Ali and Pattison (2013) note:

Within the specialist branches of modern medicine, it can no longer be assumed that Muslim medical professionals are able to provide the holistic approach of their counterparts from earlier centuries. Seen in this light, the evolving role of Muslim chaplains in healthcare today could be seen perhaps as helping to revive the spiritual dimensions of patient care, this time as part of a multi-professional medical team. (p. 34)

It is this holistic approach which incorporates the spiritual, behavioral, and social sciences that most informs the spiritual and emotional support, healing, and guidance that a Muslim chaplain provides wherever he or she serves. In fact, due to this holistic approach the Muslim chaplain is often called upon to help improve the lives of Muslims and non-Muslims experiencing moral, existential, and spiritual distress in relation "to changes in health, maturation, ability, and life circumstances" (Canadian Association for Spiritual Care, 2016, p. 1). As such, the most effective Muslim chaplain is not only trained in the religious sciences, but is also informed by what the CASC describes as "a holistic understanding of human life as spiritual, biological, psychological, social, and cultural" (Canadian Association for Spiritual Care, 2016, p. 2).

As with Islamic counseling and psychotherapy in general (Dharamsi \& Maynard, 2012), Islamic pastoral care is also "based on a coherent body of work derived from Islamic sciences and practices that are therapeutic in nature" ( $p$ 141). As the research of Isgandarova and O'Connor (2012) indicates, Islamic pastoral care providers integrate "theories of psychology and social sciences together with the traditional sources of Islamic spiritual care" (p. 3). While this critical engagement with psychology and the social sciences is still emerging within the professional literature (e.g., Isgandarova, 2014; Isgandarova \& 
O'Connor, 2012), it is present within the dynamic and critical dialogues taking place between Muslim chaplains and counseling professionals at professional chaplaincy events and within Islamic chaplaincy programs. Often this critical dialogue is related to how Muslim chaplains can integrate diverse psychotherapeutic approaches while remaining faithful to the Islamic framework that is the basis of their care. As Isgandarova (2013) notes, "[the] traditional Islamic texts and the life of the Prophet Muhammad are the essential foundations of Islamic spiritual and religious care; otherwise, caregiving is not truly Islamic" (p. 111).

\section{Scope of Practice}

Despite the history and growth of the field of Muslim chaplaincy, it has been inhibited by ambiguous and unsatisfactory descriptions as the profession has sought to define itself. This ambiguity has led to confusions over the role of a Muslim chaplain and his or her relationship with the position and function of an imam. To add clarity where there is ambiguity within the literature, we propose the following definition:

Muslim chaplaincy is the pastoral care of Muslims within institutional settings. It primarily serves the needs of those who may be experiencing, or at risk of experiencing, spiritual, social, psychological, and physical distress. It may be provided through a number of interventions including spiritually-integrated psychotherapy, spiritual mentorship, education, advocacy, and a caring relationship. Although Muslim chaplains specialize in the pastoral care of those in distress, they may also contribute to the sense of joy and thankfulness within his or her community or institution by leading celebrations and prayers at times of success, joy, and the sacred days of the Islamic year. While Muslim chaplaincy can and does serve the needs of people of other faiths, or no faith at all, the Muslim chaplain is unique in his or her ability to provide specialized care and services that are relevant and meaningful to Muslims within an institutional context. In doing so, the Muslim chaplain strives to provide his or her services in ways consistent with the principles of the Islamic tradition, such as its emphasis upon guidance (irshad) and mercy (rahma), no matter who the chaplain is serving (Muslim or non-Muslim). Furthermore, Muslim chaplaincy differs from other ways of serving the community (khidma) by being founded upon the principles of reformation (islah) of the spiritual heart (qalb) and a psychological understanding of wellbeing, healing, and growth.

\section{Qualifications}

The requisite skills and qualifications necessary to serve as a Muslim chaplain vary from sector to sector, and institution to institution. However, a lack of standardization for entry into the profession has allowed for a wide vari- 
ety of individuals with varying degrees of education, training, and experience to serve in various institutions. While this lack of standardization has been a concern for those seeking to set clearer professional standards, it has enabled individuals with a wide range of expertise, experience, and qualifications to join the profession (and, in certain cases, to serve each other as consultants on unique cases). While most Muslim chaplains have at least a foundational religious education or understanding of the Islamic sciences, a growing number have received or are pursuing advanced education in pastoral care, counseling, psychology, and Islamic studies. This may be attributed, in part, to the rigorous standards set by some institutions (such as hospitals and the armed forces), but also to the gradual professionalization of the field and the development of graduate-level Islamic chaplaincy programs.

The most rigorous standards for chaplaincy work are set by professional chaplaincy associations, such as the Association of Professional Chaplains (APC) in the United States and the Canadian Association for Spiritual Care (CASC) in Canada. Each of these associations require those seeking professional certification to possess a graduate theological degree (M.Div or equivalent), complete 1,600 hours of clinical pastoral education (CPE), and undergo a review of professional competencies by a board of certified chaplains. Of these, it is the CPE training that most informs a chaplain's work; helping the chaplain to integrate "clinical skills with knowledge of self and knowledge of religious, spiritual, philosophical, psychological, and cultural frameworks" (Canadian Association for Spiritual Care, 2016, p. 2). Comparable to the practicum component in social work and counseling degrees, CPE programs place learners in clinical environments where they engage in applying their skills and counseling techniques under the supervision of certified professionals. As Kowalski and Becker (2015) note:

CPE programs use observation and practice, similar to the clinical training of physicians, to train [religious care providers] how to minister to the sick. In the CPE model, the seminary student or [religious care provider] intern visits patients onsite, in hospital and other clinical settings, while simultaneously learning pastoral counseling techniques and receiving critical feedback from supervisors and peers. (pp. 25-26)

While hospitals and the armed forces often require at least 400 hours of CPE (Kowalski \& Becker, 2015), other institutions including a number of prisons and universities often do not require any CPE training though they may highly recommend it. However, standards for hiring and practice within each sector may increase over time as the profession continues to develop. 


\section{Different from Imams}

Although certain responsibilities, skills, and competencies are shared between imams and Muslim chaplains, the two roles differ in their gender specifications, settings, and scope of practice. While the position of imam is traditionally held by men, both women and men may serve as Muslim chaplains. This is due, in part, to differences in the primary functions of their roles. Though an imam's duties can vary significantly from one mosque to another, his primary responsibility is typically to lead congregational prayers and provide Jumu'ah (Friday prayer) sermons; roles traditionally limited to men. However, the primary responsibility of a Muslim chaplain is the pastoral care of individuals (Muslim and non-Muslim) in public institutions (e.g., hospitals, universities, the military, and correctional facilities) which both Muslim women and men may engage in. Furthermore, effective Muslim chaplaincy requires extensive training in pastoral care, counseling, and professional ethics. However, despite the value such training could provide for imams serving Muslim communities, most imams have not received formal training in counseling or pastoral care (Ali et al., 2005). In fact, as Isgandarova (2014) argues, many "faculties of Islamic theological studies," including those that train imams, "fail to initiate creative resources in order to produce religious leaders that meet the psychosocial needs of the Muslim community" (p. 218). This lack of training in psychology, counseling, and pastoral care, as Isgandarova (2013) further notes, "undermines [an imam's] effectiveness in terms of being able to respond to the emotional and relational needs of Muslims" (p. 114). Furthermore, due to "the nature of modern public institutions, with their concerns about security, health [,] safety, and confidentiality," (Gilliat-Ray, Ali \& Pattison, 2013, p. 41) a Muslim chaplain serving within an institution has greater access (than a visiting imam) to offer spiritual care and work in collaboration with psychologists, psychiatrists, and other care providers.

\section{Case Study}

Anah, a 19-year-old Muslim woman, was an outpatient in an eating disorders program at a psychiatric hospital. For several weeks, she met with her psychiatrist who oversaw her treatment plan which included eating meals at specific times of the day. Although Anah was making progress, her situation become complicated when she informed her psychiatrist that Ramadan, a sacred month devoted to fasting, was nearing and that she intended to fast. Anah's psychiatrist expressed concern that her fasting could negatively impact her health. However, Anah explained that fasting was a religious obligation in her faith. 
Anah's psychiatrist contacted the hospital's Muslim chaplain to consult with him about the matter. The psychiatrist expressed respect for Anah's faith but was concerned that her desire to fast may be linked with her eating disorder. The Muslim chaplain confirmed that fasting during Ramadan is, indeed, an obligation for adult Muslims. However, he also informed her that there are certain circumstances that would remove this obligation; especially in matters of health. The psychiatrist then asked if she could refer Anah to him. He informed her that she could and that he would be happy to support Anah's psychiatric treatment through faith-based care. Anah's psychiatrist then informed her about her conversation with the hospital's Muslim chaplain and recommended that she speak with him. She agreed.

Anah met with the Muslim chaplain in the counseling room of the hospital's pastoral care office. He informed her that he, like her psychiatrist, was also bound by a confidentiality agreement and encouraged her to speak freely. Anah expressed thanks for meeting and explained that this was the first time for her to speak openly about her eating disorder with a Muslim "religious leader." He expressed that he was honored and then proceeded to empathetically assess her concerns. Anah explained that she understood how fasting during Ramadan would worry her psychiatrist, however Anah felt anxious and unsure about how "skipping Ramadan" might negatively impact her faith. She further explained that her Islamic faith was a comfort to her and that she enjoyed sharing in certain practices, like fasting and breaking fast, alongside her family. Moreover, she worried that if she did not fast Ramadan, then she would feel like a "bad Muslim."

The Muslim chaplain informed Anah that before they met he had privately consulted with several scholars about whether individuals seeking treatment for eating disorders may be excused from fasting. He related that, given her circumstances, they agreed that it would be advisable for her to maintain her treatment plan (and not fast). Anah was relieved to hear that, but she still expressed a sense of grief over not being able to "participate in Ramadan." So, the Muslim chaplain sought to help her cope by offering her a way of reframing her perspective. The Muslim chaplain ensured her that "Ramadan could be just as sacred" if Anah were to see her struggle with her eating disorder "as an act of worship." He informed her that "any good done for the sake of Allah is an act of worship" and that, whether fasting or not, all the good that she might do during Ramadan, including following her treatment plan, "would be more blessed than any other time of the year."

She expressed appreciation for hearing that. The Muslim chaplain then assessed Anah's social support network and encouraged her to plan and share in activities with those who could help her stay on track with her treatment plan and to get the most out of Ramadan. Later, when her psychiatrist followed up with the Muslim chaplain, she informed him that Anah was appreciative of the 
pastoral care she received and was now determined to make the most of Ramadan while following through with her treatment plan.

\section{Discussion}

Islamic pastoral care and Muslim chaplaincy is rooted in the Qur'an and the teachings and practices of the Prophet Muhammad who referred to the responsibility human beings have to care for each other as like that of a shepherd toward his or her flock. Islamic pastoral care is not new. However, what is new is the professionalization of Islamic pastoral care in the form of Muslim chaplaincy which, as Gilliat-Ray, Ali, and Pattison (2013) note, "provides a framework and an opportunity for the growing inclusion of Muslims in public life and society" (p. 11). Despite Christian links to the profession's terminology and development, Muslim chaplaincy in North America has emerged from the distinct needs of Muslim communities, particularly within healthcare, educational, military, and correctional settings. While still in its initial development phase, Muslim chaplaincy demonstrates a unique approach to faith-based care that brings insights and principles from the Islamic sciences together with a psychological understanding of wellbeing, healing, and growth. Moreover, while serving within public institutions, Muslim chaplains can collaborate with and work alongside psychologists, psychiatrists, and other care providers to greatly enhance the care Muslims receive.

\section{Need for Further Research}

Although Muslim chaplains have provided care in various North American institutions since the mid-twentieth century, little research has been conducted on the development and efficacy of Islamic pastoral care practices (Kowalski \& Becker, 2015; Long, 2014). Of the available studies, most focus on Islam's theoretical, theological, and historical relationship with spiritual care (Long, 2014) while only a limited amount of research has focused on documenting current practices, successes, and challenges in the field. This deficit of published literature maintains an overall lack of awareness concerning Muslim chaplaincy and the degree to which Muslim chaplains contribute to the wellbeing of Muslims and non-Muslims in public institutions (Kowalski \& Becker, 2015). As such, there is a genuine need for further research that can not only help develop the efficacy of Islamic pastoral care practices, but also identify pastoral interventions that can be taught and practiced by other Muslim and non-Muslim care providers. Not only could further research help us better understand Muslim chaplaincy, but its study can further provide us with a "litmus test for how well 
individual secular institutions cope with issues of religious and cultural pluralism" (Kowalski \& Becker, 2015, p. 18).

\section{References}

Ali, O. M., Milstein, G., \& Marzuk, P. (2005). The Imam's role in meeting the counseling needs of Muslim communities in the United States. Psychiatric Services, 56(2), 202-205. https://doi.org/10.1176/appi.ps.56.2.202.

Ansari, B. (2011). The Foundations of pastoral Care in Islam: Reviving the pastoral voice in Islamic prison chaplaincy (Master's Thesis). Hartford Theological Seminary.

Canadian Association for Spiritual Care (2016). Scope of practice. Retrieved from http:// http://spiritualcare.ca/page.asp?ID $=8$

Doehring, C. (2006). The practice of pastoral care: A postmodern approach. Louisville, KY: Westminster John Knox Press.

Dharamsi, S., \& Maynard, A. (2012). Islamic-based interventions. In S. Ahmad \& M. M. Amer (Eds.), Counseling Muslims: Handbook of mental health issues and interventions (pp. 135-160). New York: Routledge.

Gilliat-Ray, S., Ali, M., \& Pattison, S. (2013). Understanding Muslim chaplaincy. Burlington, VT: Ashgate Publishing Company.

Isgandarova, N. (2005). Islamic spiritual care in a health care setting. In A. Meier, T. S. O'Connor, \& P. VanKatwyk (Eds.), Spirituality \& health: Multidisciplinary explorations (pp. 85-101). Waterloo, ON: Wilfred Laurier University Press.

Isgandarova, N. (2008). Muslim spiritual care and counselling: A case study of a resident with Parkinson's Disease. In T. O’Connor, C. Lashmar, \& E. Meakes (Eds.), The spiritual care giver's guide to identity, practice, \& relationships: Transforming the honeymoon in spiritual care and therapy (pp. 235-242). Waterloo, ON: South Western Region of the Canadian Association for Pastoral Practice and Education \& Waterloo Lutheran Seminary.

Isgandarova, N., \& O'Connor, T. S. (2012). A redefinition and model of Canadian Islamic spiritual care. Journal of Pastoral Care \& Counseling, 66(2), 1-8. https://doi. org/10.1177/154230501206600207.

Isgandarova, N. (2013). The crescent of compassionate engagement: Theory and practice of Islamic spiritual care. In D. S. Schipani (Ed), Multifaith views in spiritual care (pp. 109-129). Kitchener, ON: Pandora Press.

Isgandarova, N. (2014). Practical theology and its importance for Islamic theological studies. Illahiyat Studies, 5(2), 217-236. https://doi.org/10.12730/13091719.2014. 52.109 .

Koenig, H. G. (1997). Is religion good for your health? The effects of religion on physical and mental health. Binghamton, NY: Haworth Pastoral Press.

Jackson, S. A. (2005). Islam and the Blackamerican: Looking toward the third resurrection. New York, NY: Oxford University Press. https://doi.org/10.1093/acprof:o so/9780195180817.001.0001.

Kassam-Remtullah, A. (2010). Chaplains. In Encyclopedia of Muslim-American history. (pp. 98-100). New York, NY: Facts on File, Inc.

Kowalski, M., \& Becker, W. (2015). A developing profession: Muslim chaplains in American public life. Contemporary Islam, 9(1),17-44. https://doi.org/10.1007/ s11562-014-0308-9. 
Long, I. J. (2014). Caring for the Muslim soul: Approaches to the spiritual care of Muslim patients. In T. S. O'Connor, K. Lund, \& P. Berendsen (Eds.), Psychotherapy: Cure of the soul (pp. 49-58). Waterloo, ON: Waterloo Lutheran Seminary. 